\title{
The invasive crayfish Faxonius immunis causes the collapse of macroinvertebrate communities in Central European ponds
}

\author{
Alexander Herrmann $(\mathbb{D} \cdot$ Karsten Grabow $\cdot$ Andreas Martens $\mathbb{D}$
}

Received: 31 August 2021/Accepted: 10 December 2021/Published online: 23 January 2022

(C) The Author(s) 2021

\begin{abstract}
The invasive crayfish Faxonius immunis is regarded as a threat to amphibians and macroinvertebrates in the Upper Rhine Valley, Germany, eradicating macrophytes and establishing high-density populations in stagnant waters. This study investigates the macroinvertebrate community structure of five conservation ponds south of Karlsruhe, Germany, to identify effects caused by this invasive crayfish. Two of the ponds had a high population density of $F$. immunis, two were expected to have lower crayfish densities as they had been habitat modified with gravelled water beds as a crayfish management approach, and one pond was known to be free of crayfish but contained fish. The macroinvertebrate communities were analyzed considering their species richness and composition. The relative density of $F$. immunis within the samples was regarded as a representative indicator for crayfish population density and tested for its influence on the ordination along with habitat composition and abiotic factors using distance-based redundancy analysis. $F$. immunis was identified as a driving factor of the macroinvertebrate communities of sampled ponds. Additionally, this study indicates that gravelling ground beds as a
\end{abstract}

Handling Editor: Télesphore Sime-Ngando.

A. Herrmann $(\square) \cdot$ K. Grabow $\cdot$ A. Martens Institute of Biology, University of Education Karlsruhe, Bismarckstraße 10, 76133 Karlsruhe, Germany e-mail: al.herrmann@web.de management method for invasive burrowing crayfish species does not significantly influence the community composition but can minimize indirect effects caused by $F$. immunis.

Keywords Decapoda - Management - Neobiota · Community ecology $\cdot$ Conservation

\section{Introduction}

Invasive non-native species are one of the biggest threats to biodiversity (Butchart et al. 2010), and invasions in freshwater habitats are of global concern (Chandra and Gerhardt 2008). They subsequently can act as driving factors in aquatic macroinvertebrate communities in rivers (Baur and Schmidlin 2008) as well as in lakes (Gergs and Rothhaupt 2015). The River Rhine itself can act as an introduction highway for aquatic invasive species (Leuven et al. 2009), and its macroinvertebrate communities are in contact with several invasive species (ICPR 2015). However, direct effects on community compositions are rarely observed, perhaps due to the complexity of the problem, which is caused by the specific ecology of invasive species (Karatayev et al. 2009). In the Upper Rhine Valley, the invasive freshwater crayfish Faxonius immunis was first detected in 1993 (Gelmar et al. 2006), spreading fast along the main river and oxbows 
(Chucholl 2012). By now, F. immunis has spread downstream to the federal state of Hesse (Herrmann et al. 2018b) with an isolated population in the city of Duesseldorf in the federal state of North RhineWestphalia, Germany (Gross 2019). The spread of $F$. immunis is not limited to the main river and its oxbows, and it also disperses through interconnected watercourses and ditches (Chucholl 2012; Martens 2016). The species is able to disperse over land and populate isolated ponds next to its habitat of origin at any time of the year (Herrmann et al. 2018a). This also happens for temporary ponds created for nature conservation, where the crayfish can be a threat to animals like the lilypad whiteface Leucorrhina caudalis or the European tree frog Hyla arborea, which are protected under the European Bird's and Habitats Directive (European Economic Community 1992). F. immunis is known as a burrowing species (Hobbs and Hart 1959) that is defined as a tertiary burrower (Berrill and Chenoweth 1982). It can build high population densities in ponds and oxbows (Goellner 1943; Crocker and Barr 1968; Chucholl 2012), changing the habitat drastically by reducing aquatic macrophytes to a minimum and increasing turbidity of the waterbody (Martens 2016).

As the species reaches its highest densities in small ponds, it is crucial to understand the invasive potential in these locations. Studies derived from oxbows and rivers cannot reveal the role of this invader in these other highly invaded habitats. The present study compares the macroinvertebrate communities of five conservation ponds with different stages of applied habitat management and $F$. immunis population density to investigate effects caused by this invasive crayfish species and to test whether Faxonius immunis is a driving factor within the macroinvertebrate communities.

\section{Materials and methods}

\section{Sampling}

The sampled ponds (Table 1) were chosen based on crayfish density, comparability, accessibility and the level of gravelling the bottom sediment as management approach. They are located near the city of Rheinstetten and the community of Durmersheim, south of Karlsruhe, Germany. This area is part of the
Upper Rhine Valley, which is known as a hot spot for biodiversity in Europe (Ackermann and Sachtleben 2012).

Pond A was created in 2014 as part of the EU-Life+ -Project "Rheinauen bei Rastatt" in the area Heilwald at the community of Durmersheim. It was monitored for dragonflies and for molluscs in the context of technical reports on the success of the project in 2015 (Schiel 2015; Groh and Richling 2015). In the same year, pond A was described as a well-developing habitat with diverse aquatic vegetation and a good suitability as dragonfly habitat. In 2017, the pond first appeared turbid and seemed to have lost almost all of its aquatic macrophytes. It was chosen because there was a remarkably high population density of $F$. immunis known. In 2017, a population density of 10.47 individuals $/ \mathrm{m}^{2}$ was estimated using a mark-recapture method (own unpublished data).

The ponds B, C, D and G (Table 1) were created for threatened amphibians and used as ecological compensation for the construction of communal infrastructure and are part of an area with more than 10 ponds in the city of Rheinstetten, south-western Germany. The last changes made to the ponds had been maintenance to pond B in 2014 and the gravelling of pond C and D in the years 2017 and 2019. The conservation area in Rheinstetten is a relevant habitat of rare amphibian species like the European tree frog Hyla arborea, the northern crested newt Triturus cristatus and the agile frog Rana dalmatina (Beck und Partner 2014), which are listed in the EU directive 92/43EEC (European Economic Community 1992). The ponds are also habitat for different rare invertebrate species such as great silver water beetle Hydrophilus piceus and the lilypad whiteface Leucorrhina caudalis (own unpublished data).

$F$. immunis is widespread in the area. In these summer-warm ponds with mud or clay as main substrate, F. immunis builds high population densities. Only single ponds could be managed to have low crayfish abundances (C, D), achieved by a combination of habitat modification by gravelling the bottom sediment and reducing the population by removing crayfish over multiple years. In the context of gravelling the sediment, a part of the water surface was lost; therefore, the ponds dried out to a bigger part. Ponds B and C have had a known population of the invasive common sunfish Lepomis gibbosus. One 
Table 1 Sampled ponds in the city of Rheinstetten and the community of Durmersheim with coordinates in decimal grades (for World Geodetic System 1984 [WGS 84]), approximate maximal depth, known fish population, expected densities of Faxonius immunis and their level of habitat modification

\begin{tabular}{|c|c|c|c|c|c|c|}
\hline & Coordinates & $\begin{array}{l}\text { Area } \\
{\left[\mathrm{m}^{2}\right]}\end{array}$ & $\begin{array}{l}\text { Approx. max. } \\
\text { depth }[\mathrm{m}]\end{array}$ & Fish & $\begin{array}{l}\text { F. immunis } \\
\text { density }\end{array}$ & $\begin{array}{l}\text { Habitat } \\
\text { modification }\end{array}$ \\
\hline A & $\begin{array}{r}48.949187, \\
8.281924\end{array}$ & 481.9 & 1.7 & None & High & None \\
\hline B & $\begin{array}{r}48.973105 \\
8.294864\end{array}$ & 2918.2 & 1.6 & Lepomis gibbosus & High & None \\
\hline $\mathrm{C}$ & $\begin{array}{r}48.971479 \\
8.293772\end{array}$ & 2893.4 & 1.5 & Lepomis gibbosus & Low & Medium \\
\hline D & $\begin{array}{r}48.971493 \\
8.295961\end{array}$ & 2115.6 & 1.0 & None & Low & High \\
\hline G & $\begin{array}{r}48.970317 \\
8.298021\end{array}$ & 1441.9 & 1.8 & $\begin{array}{l}\text { Lepomis gibbosus, Rutilus rutilus, Scardinius } \\
\text { erythrophthalmus }\end{array}$ & Null & None \\
\hline
\end{tabular}

single pond is free of crayfish (G) with known populations of the common rudd Scardinius erythrophthalmus and the common roach Rutilus.

Macroinvertebrates were sampled monthly in March, April and May 2019. Samples in each pond were taken using a telescopic gabion dip net (WINLAB ${ }^{\circledR}, \emptyset 200 \mathrm{~mm}, 1.5 \mathrm{~mm}$ mesh size). At the ponds, representative microhabitats were identified and partitioned to the sum of 5 microhabitats per sampling period per pond prior to sampling. Abiotic factors (temperature, $\mathrm{pH}$ ) were recorded at the start of the sampling using a digital thermometer (GTH 1160) and $\mathrm{pH}$ meter (Voltcraft PH 100 ATC). The collection of macroinvertebrates consisted of ten standardized 1-m swipes per microhabitat. The retrieved material was collected in buckets, sieved over a framed $500 \mu \mathrm{m}$ mesh and sorted alive before processing to 1-L polypropylene (PP) flasks. Amphibian larvae, bigger plant parts and stones received during the collection were put back into the water before further sorting. To prevent the collected wet material from diluting the medium too much, $96 \%$ ethanol was used for conservation in the field.

Field samples were transported to the laboratory and partitioned to bigger (e.g. juvenile crayfish, water beetles, dragonfly larvae) and smaller (e.g. chironomids, small damselfly larvae) specimens samples, and $96 \%$ ethanol was renewed prior to identification. A list of the literature used for identification is provided in supplementary material. Macroinvertebrates were counted and identified using a Leica EZ4 stereo microscope and the latest literature. Where possible, specimens were identified to species level and processed to fresh $70 \%$ ethanol. In Diptera, identification to species level was sparse and the genus- or (sub-, super-) family level was taken. The same was true for undescribed larval stages in Odonata, Coleoptera and Heteroptera.

Data analysis

Abiotic parameters and habitat compositions were carried to an explanatory factor matrix, together with corresponding levels of habitat modification. A complete list of abiotic and habitat parameters including the data type is provided in the supplements. To investigate the effect of management through habitat modification, the level of management was quantified using a 3 -level scale $(0 ; 0.5 ; 1)$. The 0.5 level describes pond $\mathrm{D}$, where larger areas of the shore are covered with Phragmites australis and could therefore not have been gravelled completely (Table 1).

The factor identifying the relative density of $F$. immunis was created using the absolute count of $F$. immunis specimen per sample and dividing it by the total count of macroinvertebrate individuals within the same sample. The species was not taken as a response variable and therefore was removed from the macroinvertebrate dataset. The environmental factors were scaled relative to each other to values between 0 and 1 to ensure comparability using the decostand command within the package vegan 2.5-6 (Oksanen et al. 2019) 
for the program R (R Core Team 2013). Each pond was tested for its absolute species richness and Shannon index, and evenness was checked for a first comparison of sites. The diversity indices taken from the Shannon index output were later analyzed towards their correlation with the density factor of $F$. immunis. The regression was tested using a general linear model (Gaussian family).

A dissimilarity matrix was created from the abundance data matrix. Because the macroinvertebrate dataset incorporated many rare species and the matrix therefore contained about $82 \%$ zero entries, BrayCurtis dissimilarities were taken. To minimize the effect of outliners on the community dissimilarities of samples and to set focus on the composition of communities, the macroinvertebrate abundance data were fourth root transformed prior to analysis (Anderson et al. 2011). A hierarchical cluster analysis (McQuitty 1966) was performed prior to further analysis to test whether the sample dissimilarities matched the expected patterns.

Factors for model creation were selected using the bioenv command from vegan $2.5-6$, which finds the best subset of environmental variables, so that the Euclidean distances of scaled environmental variables have the maximum correlation with macroinvertebrate community dissimilarities (Clarke and Ainsworth 1993). A distance-based redundancy analysis (dbRDA) (Legendre and Anderson 1999) was chosen to test the influence of selected factors on the macroinvertebrate communities. The significance of chosen factors was tested subsequently following the suggestions of McArdle and Anderson (2001). The received cumulative $\mathrm{R}^{2}$ of the significant model, which can be displayed to high, was then corrected according to Legendre et al. (2011). Using variation partitioning (Borcard et al. 1992) by the varpart command from the vegan (3.5-6) package, the adjusted $\mathrm{R}^{2}$ per explanatory factor was also calculated separately (Gherardi 2007).

\section{Results}

\section{Biodiversity}

In the present study, a total of 98 taxa were found within the 15 samples. Species richness was highest for pond G, where Faxonius immunis was not present, with 464 individuals from 52 taxa. The minimal count derived from the sample of pond A taken in May 2019 with six taxa, while the proportion of $F$. immunis within the sample was $87.34 \%$ of the individuals. Water temperatures during the study ranged from 13.4 $( \pm 1.1){ }^{\circ} \mathrm{C}$ in March to $21.4( \pm 2.0){ }^{\circ} \mathrm{C}$ in May and did not differ significantly between the sampled ponds. Emerging taxa abundances decreased gradually with rising water temperatures. The Shannon diversity index taken per pond showed a negative relation with F. immunis density (Fig. 1). The applied general linear model revealed significance of the regression between the abundance-based factor describing $F$. immunis density and decreasing species richness $\left(\mathrm{R}^{2}=-0.82\right.$, $p>0.001)$.

The species richness declined from March to May, while the relative abundance of $F$. immunis increased for ponds containing the species. Pond $\mathrm{C}$ marks the exception with a known small population of $F$. immunis, which was not represented within the samples taken for pond C (Table 2). Ponds A and B were characterized by exceptionally low total abundances of macroinvertebrates. They contained 85\% less Mollusca, 98\% less Ephemeroptera larvae and 98\% less Odonata larvae compared to the crayfish-free pond $\mathrm{G}$ (Fig. 2). For pond A, species richness declined from 22 to 5 detected species over the sampling period. The abundances of aquatic Heteroptera were highest for pond $\mathrm{C}$ with 148 individuals.

The complete abundance data table containing all taxa and individual counts per sample is provided in supplementary material.

\section{Dissimilarity}

Hierarchical cluster analysis clearly separated samples of ponds taken in March and April from those sampled in May 2019 at the $90 \%$ dissimilarity level. The crayfish-free pond $G$ clusters isolated and shows highest similarity with itself over the whole sampling period (Fig. 3). The ponds B-G show similarities within the samples from March and April.

\section{Community analysis}

The best subset of environmental variables, as selected by the bioenv function, included water temperature (T), proportion of Juncus spp. and mud as microhabitat compartments and the abundance-based factor for 


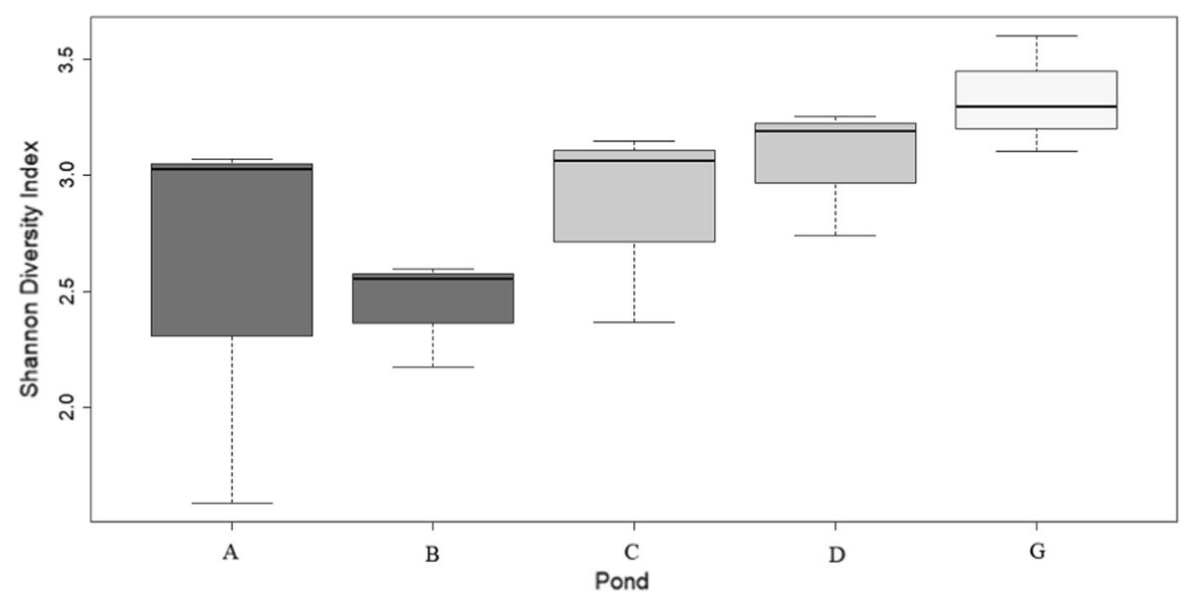

Fig. 1 Shannon diversity indices during the sampling period for the sampled ponds with high population densities of Faxonius immunis (dark grey), managed ponds with low densities (light grey) and the crayfish-free pond (white). Whiskers marking the total range

Table 2 Total counts for taxa and number of individuals (without F. immunis) and total counts as well as relative proportion of F. immunis per sample in five ponds north of Karlsruhe, Germany

\begin{tabular}{|c|c|c|c|c|c|}
\hline \multirow[b]{2}{*}{ Pond } & \multicolumn{3}{|l|}{ Sample } & \multicolumn{2}{|c|}{ F. immunis } \\
\hline & Sample & Taxa & Individuals & Total & Relative \\
\hline \multirow[t]{3}{*}{ A } & March & 22 & 68 & 1 & 0.015 \\
\hline & April & 21 & 45 & 27 & 0.375 \\
\hline & May & 5 & 13 & 90 & 0.874 \\
\hline \multirow[t]{3}{*}{ B } & March & 38 & 184 & - & - \\
\hline & April & 28 & 66 & 20 & 0.230 \\
\hline & May & 23 & 38 & 43 & 0.530 \\
\hline \multirow[t]{3}{*}{$\mathrm{C}$} & March & 14 & 171 & - & - \\
\hline & April & 26 & 274 & 2 & 0.007 \\
\hline & May & 16 & 49 & 12 & 0.197 \\
\hline \multirow[t]{3}{*}{ D } & March & 14 & 171 & - & - \\
\hline & April & 14 & 317 & - & - \\
\hline & May & 9 & 105 & - & - \\
\hline \multirow[t]{3}{*}{ G } & March & 27 & 93 & - & - \\
\hline & April & 23 & 130 & - & - \\
\hline & May & 11 & 92 & - & - \\
\hline
\end{tabular}

Faxonius immunis with a correlation of $69.3 \%$. The applied db-RDA clearly showed gradient-driven ordination towards the density of Faxonius immunis (Fig. 4). The explained variation from the db-RDA output was $40.9 \%$ after correction of $\mathrm{R}^{2}$. As the first two axes together account for $69.71 \%$ of the ordination, a 2-dimensional plot was chosen.

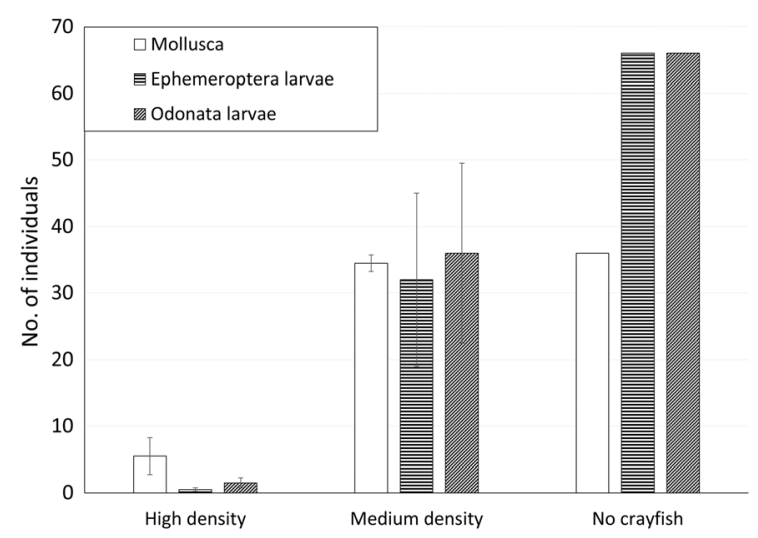

Fig. 2 Number of individuals caught within the taxonomic groups of Mollusca, Ephemeroptera and Odonata larvae for high-density ponds, managed ponds with lower crayfish densities and the crayfish free pond. Error bars indicating the standard error within the data row. The row for pond $\mathrm{G}$ has no error bar and is only given for optical comparability

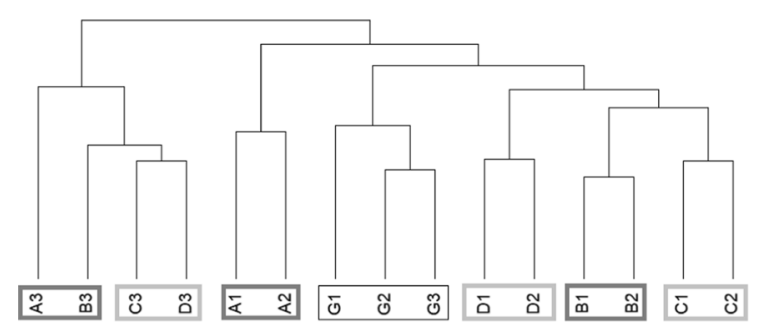

Fig. 3 Hierarchical cluster analysis of similarities for samples taken from the studied ponds A, B, C, D and G, in March, April and May (1, 2 and 3), respectively. Marked abbreviations highlight high ponds with high densities of $F$. immunis (dark grey), managed ponds with lower crayfish densities (light grey) and the crayfish free pond (thin line) 


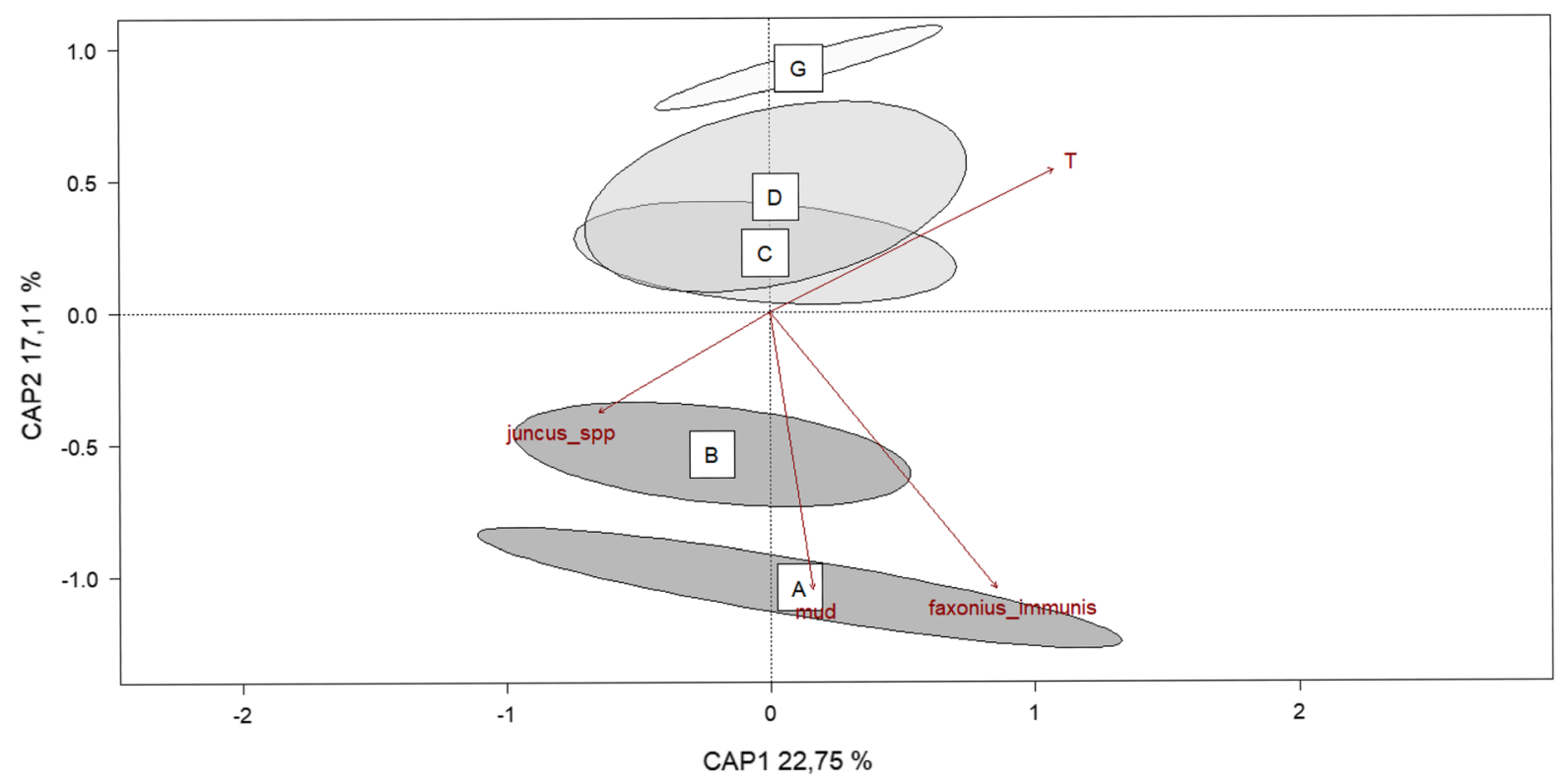

Fig. 4 Distance-based redundancy analysis of the identified subset of explanatory factors including Faxonius immunis in small ponds. The imaginary orientation along the axis seems equal to the density gradient of sampled ponds. Only the first two axes of the correlation biplot with their value of explained

The variance inflation factors of the chosen subset did not show signs of multicollinearity and ranged from 1.12 to 1.79 (Table 3). The variation partitioning algorithm showed little overlap between factors. The proportion of total variance explained by each single factor was highest for Faxonius immunis (13.27\%), followed by water temperature $(12.2 \%)$ and lower for Juncus spp. (8.92\%) and mud (6.38\%) as microhabitat proportions of the ponds. total variation are shown. Ellipses display score groupings of sampled sites for high-density ponds A and B (dark grey), managed ponds with lower crayfish densities $\mathbf{C}$ and $\mathbf{D}$ (light grey) and the crayfish free pond $\mathrm{G}$ (white)

\section{Discussion}

The present study clearly shows strong impacts of Faxonius immunis on the studied macroinvertebrate communities. The decrease in macroinvertebrate abundances, Shannon biodiversity indices and $\alpha$ diversity along a crayfish-density gradient and the resulting increase in its dominance is clearly visible. Changes in macroinvertebrate community structure as well as the differences visualized in the db-RDA ordination are oriented along the density gradient as well. Previous findings reporting effects of crayfish invasions on macroinvertebrate communities in North

Table 3 Subset of factors with their variance inflation factors (vif), biased and adjusted $\mathrm{R}^{2}$ as well as $\mathrm{p}$-values and degrees of freedom (F) Taken from the margin test output

\begin{tabular}{llllll}
\hline Factor & vif & $\mathrm{F}$ & $\mathrm{R}^{2}$ & adjusted $\mathrm{R}^{2}$ & $p$ value \\
\hline Faxonius immunis & 1.794 & 3.0186 & 0.19425 & 0.13227 & $0.001 * * *$ \\
Water temperature & 1.161 & 3.1621 & 0.18465 & 0.12193 & $0.001 * * *$ \\
Juncus spp. & 1.125 & 3.0896 & 0.15426 & 0.08920 & $0.001 * * *$ \\
Mud & 1.763 & 1.7123 & 0.13070 & 0.06383 & 0.090 \\
\hline
\end{tabular}

*Represents significance at the alpha $<0.05$ level 
America (Albertson and Daniels 2016) as well as studies on effects on the endemic aquatic flora and fauna by other invasive crayfish such as Pacifastacus leniusculus in Sweden and England (Nyström et al. 1996; Mathers et al. 2016) or Faxonius virilis in the Netherlands (e.g. Roessnik et al. 2017) describe similar effects. Such results were summarized and seem to overlap in most invasive, non-native crayfish species (Twardochleb et al. 2013).

The results of the present study can best be compared to documented effects of Procambarus clarkii in Spain, Portugal or Italy (Gherardi and Acquistapace 2007; Rodríguez et al. 2005; Correira and Anastácio 2008; Barbaresi and Gherardi 2000) and underlines suggested invader-specific ecological impacts of $F$. immunis as pronounced by Chucholl and Chucholl (2021). The relations between $F$. immunis density and $\alpha$-diversity outline the relevance of ongoing crayfish management in areas where rare macroinvertebrate species occur. With its strongly r-selected life history (Tack 1941; Chucholl 2012) and its ability to migrate over land (Herrmann et al. 2018a), F. immunis will be a growing threat for macroinvertebrate communities and ecosystem services along waterbodies invaded by this crayfish species.

The macroinvertebrate communities from ponds with high $F$. immunis densities in the present study were characterized by very low abundances in macrophyte-associated taxa, especially Odonata larvae and Mollusca. Even Ephemeroptera larvae, such as Cloeon dipterum, a species which was expected to be unaffected by the crayfish, had very low abundances in samples from high-density ponds. The effect on Odonata and Mollusca was most radical in pond A, which was monitored for dragonflies and molluscs in 2015 , one year after its creation. It was documented as a very suitable habitat for dragonflies with eleven reproducing species (Schiel 2015). In 2019, after the F. immunis invasion, only two specimens derived from one species were present within the samples from pond A. In contrast to the seven recorded aquatic mollusc species in 2015 (Groh and Richling 2015), none was found again in the present study. It is known that habitat structure and complexity has mediating effects on predatory taxa (Warfe and Barmuta 2004), such as odonata larvae. Although there are known negative effects on aquatic snails caused by crayfish predation (Nyström and Pérez 1998), no such population collapse was documented. However, Holdich (1999) suggests that total collapses of taxa can be caused by established high populations of invasive crayfish. Enclosure experiments also showed eradication of snails by an invasive non-native crayfish species (Chucholl 2013).

Incomplete sampling or effects on sample composition caused by the sampling method should not have played a major role in this study. García-Criado and Trigal (2005) compared sampling techniques for pond macroinvertebrate communities and found that 1-m swipes, as used in this study, give the most complete view on the macroinvertebrate communities in sampled ponds. Merolimnic species were abundant in all samples taken in March and April. Therefore we explain the increasing differences from March to May between the macroinvertebrate community samples, namely a drastic reduction in $\alpha$-diversity and total abundances, with the increasing activity of $F$. immunis adults with rising water temperatures in spring (Crawshaw 1974) and the presence of newly hatched juvenile crayfish in April and May (Tack 1941; Chucholl 2012).

As crayfish can act as ecosystem engineers (Statzner et al. 2000; 2002), the effects of their invasion are not caused by predation alone but also by indirect methods (Momot 1995; Nyström et al. 1996). F. immunis can cause indirect effects linked to its abundance through changes in habitat structure, as the species is known to reduce macrophytes to a minimum (Tack 1941; Letson and Makarewicz 1994) and is described as a tertiary burrowing species (Hobbs and Hart 1959; Crocker and Barr 1968; Berrill and Chenoweth 1982) that increases the turbidity of the waterbody (Martens 2016). In the present study, the effects on the habitat caused by high densities of $F$. immunis are clearly visible in pond A, where the only cover left for macrophyte-associated taxa like Odonata or Coleoptera larvae is stocks of Juncus spp. and Phragmites australis at the edge of the littoral zone with the major habitat compartment consisting of muddy ground. As aquatic macrophytes and Characeae are reduced by $F$. immunis, mud becomes the dominant microhabitat structure in ponds with high crayfish densities. The increase in muddy character of a pond and the reduction of aquatic macrophytes is therefore one of the main indirect effects caused by this invasive crayfish. Roessnik et al. (2017) described negative effects on aquatic macrophyte abundances 
linked to the density of Faxonius virilis, an invasive species in the Netherlands. In their study, crayfish significantly reduced macrophytes starting from a crayfish density of 1.25 crayfish per $\mathrm{m}^{2}$. Although mud lost its significant $p$-value in the present study after variation partitioning, it was left in the ordination because it is one of the main indirect effects of $F$. immunis.

Following this change in habitat composition, $F$. immunis indirectly changes the macroinvertebrate community composition in favour of mobile and pioneer species with lesser need for cover, while abundances of macrophyte-associated species and slow-moving taxa decrease. This effect was also described for the invasive crayfish Pacifastacus leniusculus in Sweden, where ponds with higher crayfish density inhabited mostly ground dwelling species such as Chironomid larvae or mobile taxa like aquatic Heteroptera (Nyström et al. 1996). Negative effects on the macroinvertebrate communities by predation and changes in food webs caused by Procambarus clarkii are frequently described and reviewed by Souty-Grosset et al. (2016). Shallow, fish free ponds in Central Europe are normally free of crayfish. The communities associated with this habitat therefore could be seen as naïve to omnivorous crayfish, as the top predators in the pond communities are dragonfly and water beetle larvae. This might intensify the effect on the community as well.

Gravelling the ground beds to manage $F$. immunis in ponds does not reduce the crayfish density itself, but the effects on habitat composition can be largely negated. While macrophytes density might still decrease, there is cover for macroinvertebrates as well as amphibian larvae between the gravel stones. Similar effects are known for rocks of different size that are deterring crayfish predation on fish larvae (Savino and Miller 1991). The increase in turbidity and muddy character of ponds is weakened in ponds with gravelled beds (Borner et al. 1997), which seems to counteract the main indirect effects caused by $F$. immunis on macroinvertebrate community structure in the present study as the species prefers muddy grounds (Caldwell and Bovbjerg 1969; Bovbjerg 1970). This management approach does not significantly alter the community composition itself, as the cluster analysis revealed seasonal clustering of samples taken in March and April for the ponds B, C, D and G, respectively. Therefore, the differences occur mainly with rising activity and the increasing number of juveniles of $F$. immunis.

Faxonius immunis significantly alters the macroinvertebrate community and strongly changes the habitat composition in stagnant waters by predation and otherwise reducing macrophytes. Larvae of threatened and rare macroinvertebrate species, herbivores or aquatic snails are no longer able to find the needed refuge, prey or grazing substrate between submerged macrophytes in habitats colonized by $F$. immunis. Only mobile and pioneer species seem to sustain in areas where this invasive crayfish species has built high densities. Without applied management, habitats invaded by $F$. immunis act as traps for macroinvertebrates trying to reproduce and are lost for conservation purposes.

Acknowledgements We are indebted to Louisa Rothmeier and Henry Lippmann for their help during the sampling period. Special thanks go to Meike Koester and René Sahm for their thoughtful discussions and aid towards statistical analysis.

Authors' contributions All authors contributed to the study conception and design. Final conception, field sampling and data analysis were performed by Alexander Herrmann. Identification was done by Alexander Herrmann with support from Karsten Grabow and Andreas Martens. The first draft of the manuscript was written by Alexander Herrmann, and all authors commented on previous versions of the manuscript. All authors read and approved the final manuscript.

Funding This study is supported by the Nature Conservation Foundation of Baden-Wuerttemberg with earmarked funds from lottery (ID: 73-8831.21/546 91-1744GL).

Data availability The environmental dataset and species lists for the sampled ponds will be provided as supplementary material. All raw data and the conserved macroinvertebrate samples are available at the institute and can be viewed on reasonable request.

Code availability For analysis, the Software R Studio was used. The custom R code used for analysis is available from the corresponding author under the provided e-mail address.

\section{Declarations}

Conflict of interest The authors declare that they have no conflict of interest to declare.

Ethical approval All animals were handled according to the German laws and ethics. The local administrations and responsible officials were informed and approved the study. No specific ethics approval was needed. 
Consent to participate All authors and persons named in acknowledgements section are in consent about the manuscript submission in its actual state.

Consent for publication All authors are in consent that the present results should be published.

Open Access This article is licensed under a Creative Commons Attribution 4.0 International License, which permits use, sharing, adaptation, distribution and reproduction in any medium or format, as long as you give appropriate credit to the original author(s) and the source, provide a link to the Creative Commons licence, and indicate if changes were made. The images or other third party material in this article are included in the article's Creative Commons licence, unless indicated otherwise in a credit line to the material. If material is not included in the article's Creative Commons licence and your intended use is not permitted by statutory regulation or exceeds the permitted use, you will need to obtain permission directly from the copyright holder. To view a copy of this licence, visit http://creativecommons.org/licenses/by/4.0/.

\section{References}

Ackermann W, Sachtleben J (2012) Identifizierung der Hotspots der biologischen vielfalt in Deutschland. BfN-Skripten 315:1-133

Albertson LK, Daniels MD (2016) Effects of invasive crayfish on fine sediment accumulation, gravel movement, and macroinvertebrate communities. Freshw Sci 35:644-653. https://doi.org/10.1086/685860

Anderson MJ, Crist TO, Chase JM, Vellend M, Inouye BD, Freestone AL, Sanders NJ, Cornell HV, Comita LS, Davies KF, Kraft NJB, Stegen JC, Swenson NG, Harrison SP (2011) Navigating the multiple meanings of $\beta$ diversity: a roadmap for the practicing ecologist. Ecol Lett 14:19-28. https://doi.org/10.1111/j.1461-0248.2010.01552.x

Barbaresi S, Gherardi F (2000) The invasion of the alien crayfish Procambarus clarkii in Europe, with particular reference to Italy. Biol Invasions 2:259-264. https://doi.org/10.1023/A: 1010009701606

Baur B, Schmidlin S (2008) Effects of invasive non-native species on the native biodiversity in the river Rhine. In: Nentwig W (ed) Biological invasions. Springer, Berlin

Beck und Partner (2014) Ausgleichsmaßnahmen Zentrales Feuerwehrhaus Rheinstetten, monitoring report on the conservation area for the year 2014 (In German)

Berrill M, Chenoweth B (1982) The burrowing ability of nonburrowing crayfish. Am Midl Nat 108:199-201. https://doi. org/10.2307/2425310

Borcard D, Legendre P, Drapeau P (1992) Partialling out the spatial component of ecological variation. Ecology 73:1045-1055. https://doi.org/10.2307/1940179

Borner S, Bosser T, Eggen R, Fent K, Frutiger A, Lichtensteiger T, Müller R, Müller S, Peter A, Wasmer HR. (1997) Procambarus clarkii (Roter Sumpfkrebs) im Schübelweiher bei Küsnacht. Ökologische Situationsanalyse und Vorschläge zur Bekämpfung. EAWAG. Zürich
Bovbjerg RV (1970) Ecological isolation and competitive exclusion in two crayfish (Orconectes virilis and Orconectes immunis). Ecology 51:225-236. https://doi.org/ $10.2307 / 1933658$

Butchart SHM, Walpole M, Collen B et al (2010) Global biodiversity: indicators of recent declines. Science 328:1164-1168. https://doi.org/10.1126/science.118751

Caldwell MJ, Bovbjerg RV (1969) Natural history of the two crayfish of northwestern Iowa, Orconectes virilis and Orconectes immunis. Proc Iowa Acad Sci 76:463-472

Chandra S, Gerhardt A (2008) Invasive species in aquatic ecosystems: issue of global concern. Aquat Invasions 3:1-2. https://doi.org/10.3391/ai.2008.3.1.1

Chucholl C (2012) Understanding invasion success: life-history traits and feeding habits of the alien crayfish Orconectes immunis (Decapoda, Astacida, Cambaridae). Knowl Manag Aquat Ecosyst 404:4. https://doi.org/10.1051/ kmae/2011082

Chucholl C (2013) Feeding ecology and ecological impact of an alien 'warm-water' omnivore in cold lakes. Limnologica 43:219-229. https://doi.org/10.1016/j.limno.2012.10.001

Chucholl C, Chucholl C (2021) Differences in the functional responses of four invasive and one native crayfish species suggest invader-specific ecological impacts. Freshw Biol 66:2051-2063. https://doi.org/10.1111/fwb.13813

Clarke KR, Ainsworth M (1993) A method of linking multivariate community structure to environmental variables. Mar Ecol-Prog Ser 92:205-219

Correira AM, Anastácio PM (2008) Shifts in aquatic macroinvertebrate biodiversity associated with the presence and size of an alien crayfish. Ecol Res 23:729-734. https://doi. org/10.1007/s11284-007-0433-5

Crawshaw LI (1974) Temperature selection and activity in the crayfish, Orconectes immunis. J Comp Physiol 95:315-322

Crocker DW, Barr DW (1968) Handbook of the crayfishes of Ontario. Royal Ontario Museum by University of Toronto Press

European Economic Community (1992) Council directive 92/43EEC of 21 May 1992 on the conservation of natural habitats and of wild fauna and flora. Official Journal of the European Union L 206:7-50

García-Criado F, Trigal C (2005) Comparison of several techniques for sampling macroinvertebrates in different habitats of a North Iberian pond. Hydrobiologia 545:103-115. https://doi.org/10.1007/s10750-005-2741-5

Gelmar C, Pätzold F, Grabow K, Martens A (2006) Der Kalikokrebs Orconectes immunis am nördlichen Oberrhein: ein neuer amerikanischer Flusskrebs breitet sich schnell in Mitteleuropa aus. Lauterbornia 56:15-25

Gergs R, Rothhaupt KO (2015) Invasive species as driving factors for the structure of benthic communities in Lake Constance Germany. Hydrobiol 746:245-254. https://doi. org/10.1007/s10750-014-1931-4

Gherardi F, Acquistapace P (2007) Invasive crayfish in Europe: the impact of Procambarus clarkii on the littoral community of a Mediterranean lake. Freshw Biol 52:1249-1259. https://doi.org/10.1111/j.1365-2427.2007.01760.x

Gherardi F (2007) Understanding the impact of invasive crayfish. In: Gherardi F (ed) Biological invaders in inland waters: profiles, distribution, and threats. Springer, Dordrecht 
Goellner K E (1943) The life cycle and productivity of the crayfish, Cambarus immunis Hagen. Dissertation, University of Michigan.

Groh K, Richling I (2015) Molluskenfauna im LIFE+-Projekt „Rheinauen bei Rastatt“ - Maßnahmenkontrolle 2015. Technical Report

Gross H (2019) Erster sicherer Nachweis des Kalikokrebses in Nordrhein-Westfalen (Deutschland). forum flusskrebse 30/2019, 68-69

Herrmann A, Schnabler A, Martens A (2018a) Phenology of overland dispersal in the invasive crayfish Faxonius immunis (Hagen) at the Upper Rhine River area. Knowl Manag Aquat Ecosyst 419:30. https://doi.org/10.1051/kmae/2018018

Herrmann A, Stephan A, Martens A (2018b) Erste Funde des Kalikokrebses Faxonius immunis in Hessen (Crustacea: Cambaridae). Lauterbornia 85:91-94

Hobbs HH, Hart CW (1959) The freshwater decapod crustaceans of the Apalachicola drainage system in Florida, southern Alabama, and Georgia. University of Florida, Gainesville

Holdich DM (1999) The negative effects of established crayfish introductions. Crustacean Issues 11:31-48

International Commission for the Protection of the Rhine (ICPR) (2015) The Biology of the Rhine - Summary Report on the Rhine Measurement Programme Biology 2012/2013 and National Assessments According to the WFD Rhein 2020. Technical Report No. 227

Karatayev AY, Burlakova LE, Padilla DK, Mastitsky SE, Olenin S (2009) Invaders are not a random selection of species. Biol Invasions 11:2009-2019. https://doi.org/10.1007/ s10530-009-9498-0

Legendre P, Anderson MJ (1999) Distance-based redundancy analysis: testing multispecies responses in multifactorial ecological experiments. Ecol Monogr 69:1-24. https://doi. org/10.1890/0012-9615(1999)069[0001:DBRATM]2.0. $\mathrm{CO} ; 2$

Legendre P, ter Braak OJ, CJF, (2011) Testing the significance of canonical axes in redundancy analysis. Methods Ecol Evol 2:269-277. https://doi.org/10.1111/j.2041-210X. 2010.00078.x

Letson MA, Makarewicz JC (1994) An experimental test of the crayfish (Orconectes immunis) as a control mechanism for submersed aquatic macrophytes. Lake Reserv Manage 10:127-132. https://doi.org/10.1080/07438149409354183

Leuven SEW, Van der Velde G, Baijens I, Snijders J, Van der Zwart C, Lenders HJR, Bij de Vaate A (2009) The river Rhine: a global highway for dispersal of aquatic invasive species. Biol Invasions 11:1989-2008. https://doi.org/10. 1007/s10530-009-9491-7

Martens A (2016) Der Kalikokrebs- eine wachsende Bedrohung für Amphibien und Libellen am Oberrhein. Naturschutzinfo 2016:24-26

Mathers KL, Chadd RP, Dunbar MJ, Extence CA, Reeds J, Rice SP, Wood PJ (2016) The long-term effects of invasive signal crayfish (Pacifastacus leniusculus) on instream macroinvertebrate communities. Sci Total Environ 556:207-218. https://doi.org/10.1016/j.scitotenv.2016.01.215

McQuitty LL (1966) Similarity analysis by reciprocal pairs for discrete and continuous data. Educ Psychol Meas 26:825-831.

001316446602600402
Momot WT (1995) Redefining the role of crayfish in aquatic ecosystems. Rev Fish Sci 3:33-63. https://doi.org/10.1080/ 10641269509388566

Nyström P, Pérez JR (1998) Crayfish predation on the common pond snail (Lymnaea stagnalis): the effect of habitat complexity and snail size on foraging efficiency. Hydrobiologia 368:201-208. https://doi.org/10.1023/A: 1003266603371

Nyström P, Brönmark C, Graneli W (1996) Patterns in benthic food webs: a role for omnivorous crayfish? Freshw Biol 36:631-646. https://doi.org/10.1046/j.1365-2427.1996. d01-528.x

Oksanen J, Guillaume Blanchet F, Friendly M, et al (2019) vegan: Community Ecology Package. R package version 2.5-6

R Core Team (2013) R: A language and environment for statistical computing. R Foundation for Statistical Computing, Vienna

Rodríguez CF, Bécares E, Fernández-Aláez M, FernándezAláez C (2005) Loss of diversity and degradation of wetlands as a result of introducing exotic crayfish. Biol Invasions 7:75-85. https://doi.org/10.1007/s10530-004-9636-7

Roessnik I, Gylstra R, Heuts PGM, Specken B, Ottburg FGWA (2017) Impact of invasive crayfish on water quality and aquatic macrophytes in The Netherlands. Aquat Invasions 12:397-404. https://doi.org/10.3391/ai.2017.12.3.12

Savino JF, Miller JE (1991) Crayfish (Orconectes virilis) feeding on young lake trout (Salvelinus namaycush): effect of rock size. J Freshwater Ecol 6:161-170. https://doi.org/10. 1080/02705060.1991.9665290

Schiel FJ (2015) Erfolgskontrolle Libellen. Rheinauen bei Rastatt - Abschlussbericht 2015. Technical Report

Souty-Grosset C, Anastacio PM, Aquiloni L, Banha F, Choquer J, Chucholl C, Tricarico E (2016) The red swamp crayfish Procambarus clarkii in Europe: impacts on aquatic ecosystems and human well-being. Limnologica 58:78-93. https://doi.org/10.1016/j.limno.2016.03.003

Statzner B, Fièvet E, Champagne J, Morel R, Herouin E (2000) Crayfish as geomorphic agents and ecosystem engineers: Biological behavior affects sand and gravel erosion in experimental streams. Limnol Oceanogr 45:1030-1040. https://doi.org/10.4319/1o.2000.45.5.1030

Statzner B, Peltret O, Tomanova S (2002) Crayfish as geomorphic agents and ecosystem engineers: effect of a biomass gradient on baseflow and flood-induced transport of gravel and sand in experimental streams. Freshw Biol 48:147-163. https://doi.org/10.4319/lo.2000.45.5.1030

Tack PI (1941) The life history and ecology of the crayfish Cambarus immunis Hagen. Am Midl Nat 25:420-446. https://doi.org/10.2307/2420785

Twardochleb LA, Olden JD, Larson ER (2013) A global metaanalysis of the ecological impacts of nonnative crayfish. Freshw Sci 32:1367-1382. https://doi.org/10.1899/12-203.1

Warfe DM, Barmuta LA (2004) Habitat structural complexity mediates the foraging success of multiple predator species. Oecologia 141:171-178. https://doi.org/10.1007/s00442004-1644-x

Publisher's Note Springer Nature remains neutral with regard to jurisdictional claims in published maps and institutional affiliations. 